\begin{tabular}{|c|c|}
\hline Citation & $\begin{array}{l}\text { Jo Swinnen, Thijs Vandemoortele, (2012), } \\
\text { Trade and the political economy of standards, } \\
\text { World Trade Review, 11(3), 390-400. }\end{array}$ \\
\hline Archived version & $\begin{array}{l}\text { Author manuscript: the content is identical to the content of the published } \\
\text { paper, but without the final typesetting by the publisher }\end{array}$ \\
\hline Published version & http://dx.doi.org/10.1017/S1474745612000213 \\
\hline Journal homepage & http://journals.cambridge.org/action/displayJournal?jid=WTR \\
\hline Author contact & $\begin{array}{l}\text { thijs.vandemoortele@kuleuven.be } \\
+32(0) 16376202\end{array}$ \\
\hline IR & https://lirias.kuleuven.be/handle/123456789/343956 \\
\hline
\end{tabular}

(article begins on next page) 



\title{
Trade and the Political Economy of Standards
}

\author{
Jo Swinnen, Thijs Vandemoortele
}

LICOS Centre for Institutions and Economic Performance \& Department of Economics, University of Leuven (KU Leuven) 


\section{KULEUVEN}

\section{Abstract}

This paper reviews the emerging literature on the political economy of public standards in an open economy to explain why standards are set at certain levels, and how this affects trade. We use a simple framework to illustrate how interest groups may influence the standard-setting process, and which factors may affect the political equilibria. We analyze the relation between trade and standards, and their potential protectionist nature. We argue that standards may act as barriers or catalysts to trade, that both under- or over-standardization may occur, and that standards may serve as protectionist instruments, or not.

\section{$1 \quad$ Introduction}

Standards are increasingly important in the global trading system. Standards address a large variety of issues in consumption and production such as nutrition, safety, quality, environmental, and social concerns. There exists an extensive theoretical literature on the economics of quality regulation and standards. Initially, the main focus of this literature was on the competition and welfare effects of minimum quality standards, showing that welfare may increase or decrease with the implementation of a minimum quality standard, and that different groups in society, e.g., consumers, low and high quality producers, may gain or lose (Leland, 1979; Bockstael, 1984; Ronnen, 1991; Crampes and Hollander, 1995; Valletti, 2000).

In more recent theoretical work the focus has shifted to the analysis of the relation between trade and standards, including minimum quality standards and other types of standards such as labeling standards (Fulton and Giannakas, 2004; Roe and Sheldon, 2007) or environmental standards (Schleich, 1999). The prevailing conclusion that emerges from the theoretical literature is that standards are non-tariff barriers to trade that protect domestic producers (Barrett, 1994; Sykes, 1995; Thilmany and Barrett, 1997; Schleich, 1999; Barrett and Yang, 2001; Anderson et al., 2004; Fischer and Serra, 2000; Sturm, 2006; Sheldon, 2012). Only some authors have argued that standards are not necessarily protectionist instruments (Tian, 2003; Maertens and Swinnen, 2007; Marette and Beghin, 2010; Swinnen and Vandemoortele, 2011).

A political economy approach which allows for interest groups that influence the government is essential to understanding the standard-setting process. While there is an extensive literature on the political economy of regulation and trade policy, only recently has some work been done on the political economy of public standards to explain why standards are set at certain levels, and how this affects trade (Anderson et al., 2004; Swinnen and Vandemoortele, 2008, 2009, 2011). Given the increasing importance of standards, this is an important new research area.

In this paper we review and explain key insights from this emerging literature. We first provide an overview of how political economy models have captured various (public) standards and interest groups. Next, we use a general framework to discuss the political equilibria and factors that may influence these. Finally we analyze the relation between trade and standards, and their potential protectionist nature. 


\section{Public Standards, Interest Groups, and Government Decision-Making}

Political economy models include different groups with diverse interests in public standards. In this section we discuss how public standards and the different groups' interests are typically modeled. We use a simple framework to illustrate how these interest groups may influence the public standard-setting process.

\subsection{Standards}

A key issue is obviously how to model standards. The literature has adopted different modeling assumptions depending on which product or production process characteristic (safety, quality, social and environmental effects, ...) is regulated by the standard. Safety standards, which guarantee safety characteristics e.g. by prohibiting dangerous substances in a product, are analyzed by incorporating risk in (expected) utility and/or profit functions (Cook and Fraser, 2008; Swinnen and Vandemoortele, 2009), based on the literature on product warranties (Cooper and Ross, 1985; Emons, 1988). Quality standards ensure characteristics concerning consumer preferences about aspects of nutritional value, taste, size, life span, performance, etc. The literature on minimum quality standards (Ronnen, 1991; Boom, 1995; Crampes and Hollander, 1995; Jeanneret and Verdier, 1996; Valletti, 2000) uses a vertical differentiation framework (Spence, 1976; Mussa and Rosen, 1978; Tirole, 1988) in which consumers are heterogeneous in their willingness to pay for quality/standards. Standards that aim at regulating social and environmental issues such as the prohibition of child labor and the limitation of carbon dioxide emissions, are usually modeled as having an impact on externalities (Copeland and Taylor, 1995; Anderson et al., 2004; Fischer and Serra, 2000; Swinnen and Vandemoortele, 2008, 2009).

In general, a standard can be interpreted as a prohibition to use a cheaper technology (Swinnen and Vandemoortele, 2011). Examples are the prohibition of an existing technology (e.g. child labor) or of a technology that has not yet been used but that could potentially lower costs (e.g. genetic modification (GM) technology). Most studies therefore assume that standards raise domestic production costs (Leland, 1979; Ronnen, 1991; Valletti, 2000). In an open economy, the production costs of foreign producers (interested in) exporting to the standard-imposing country may also rise if the standard is also imposed and enforced on imported goods (Fischer and Serra, 2000). The effect on prices depends on various factors such as demand and supply elasticities and trade.

Concerning the impact of standards on domestic consumers, the common approach in the literature is to assume that consumers are ex ante uncertain about the product's characteristics. ${ }^{1}$ Standards reduce asymmetric information between consumers and producers, and create a higher willingness to pay for and thus consumption of that product, ceteris paribus.

\footnotetext{
${ }^{1}$ Only some early studies (such as Bockstael, 1984) assume that consumers can costlessly observe product characteristics.
} 


\section{KU LEUVEN}

\section{$2.2 \quad$ Interest Groups}

Standards imposed at one stage in the supply chain often impact on various other stages and therefore several supply chain participants may be affected, directly or indirectly. Some agents may be affected simultaneously as consumers, producers, or even taxpayers. Consequently a multitude of economic agents, both domestic and foreign, may have opposing or coinciding interests with respect to standards and will therefore have an incentive to try to influence government decisions on standards.

However, virtually all models in the political economy literature reduce this complexity by assuming that only two 'interest groups' try to influence the government: domestic 'producers' and 'consumers'. Domestic producers gain (lose) if the price increase (due to higher demand with the standard) is higher than the cost increase. Consumers gain if the positive utility effect (from reduced uncertainty) is larger than the price effect from the standard, and vice versa.

This simplified model may apply to various stages of the supply chain since the general terms 'producers' and 'consumers' may also point at different actors depending on which stage of the supply chain is under analysis. For example, at the processing stage, 'consumers' are retailers who source products from processors (the 'producers'). At the retail stage, the retailers are 'producers' who sell products to the final consumer.

However, the models typically ignore other interest groups affected by the standard. For example, standards may require costly enforcement and monitoring by governments. Insofar that these costs are not born by producers and/or consumers, domestic interest groups have, as taxpayers, an additional motive to influence the government's standard-setting behavior.

Additionally, some interest groups may be foreign. Foreign supply chain participants may have an interest in influencing the standard-setting process, for instance, if they experience difficulties in meeting the importing country's standard. Moreover, if the standard-imposing country is a large economy that imports a significant share of that product's world market, its standard may have an impact on the world price and affect other countries' terms of trade (Baldwin 2000). Hence, foreign interest groups may have additional motives, be it as producers or consumers, to influence the standard-setting of a large country. These termsof-trade effects could also influence the political economy in foreign countries, potentially through the World Trade Organization (WTO). ${ }^{2}$

Interest groups other than supply chain participants may also try to influence a country's standard-setting process. For example, for standards targeting externalities, NGOs may take an interest in the standard's implementation. Depending on the type of externality, e.g. social versus environmental or local versus global, different domestic or international NGOs may be involved.

In general, the literature on the political economy of standards has reduced these complexities by adopting a small economy perspective and by assuming only two interest groups: one consisting of only domestic producers and one of only domestic consumers. Enforcement costs are generally assumed to be part of the standard's implementation costs.

\footnotetext{
2 These issues are related to harmonization and mutual recognition of standards which - due to space limitations - we do not discuss in this review. We refer the reader to, amongst others, Baldwin (2000), Bagwell and Staiger (2001), Hensen and Wilson (2005), Costinot (2008), and Chen and Mattoo (2008) for analyses of these issues.
} 


\subsection{The Government}

Studies in this field have typically assumed that governments maximize an objective function which, following the protection-for-sale approach of Grossman and Helpman (1994), consists of a weighted sum of lobby contributions from interest groups and social welfare. Similar to Grossman and Helpman (1994), the set of policies available to politicians is typically restricted to implementing a public standard. ${ }^{3}$

In these studies, an interest group $j$ 's 'truthful' ${ }^{4}$ contribution schedule is of the form $C_{j}(s)=\max \left\{0 ; \Pi_{j}(s)-b_{j}\right\}$, in which $s$ is the level of the standard, and the constant $b_{j}$ represents the share of surplus income $\Pi_{j}(s)$ which the interest group does not invest in lobbying. The government's objective function is

$V(s)=\sum_{j} \alpha_{j} C_{j}(s)+W(s)$,

where ${ }^{\alpha}$ represents the relative effectiveness of interest group $j$ in lobbying the government, and welfare $W(s)$ is defined as the sum of interest groups' surplus incomes:

$W(s) \equiv \sum_{j} \Pi_{j}(s)$

The government chooses the standard's level to maximize its objective function (1). ${ }^{5}$ Each level corresponds to a certain level of interest group surpluses, and hence also to a certain level of contributions. This is driven by the functional form and truthfulness of the contribution schedules: the government receives higher contributions if the standard generates higher surpluses. Conversely, the government receives less contributions if the standard decreases interest group surpluses. Therefore maximizing interest group contributions is equivalent to maximizing their income surpluses.

\section{The Political Optimum}

The government thus sets the standard's level to maximize the weighted sum of interest groups' income surpluses and social welfare. The politically optimal standard, $S^{*}$, is therefore determined by the following first order condition, subject to $s^{*} \geq 0$ :

\footnotetext{
${ }^{3}$ There are some differences in specific assumptions. For example Swinnen and Vandemoortele (2011) assume that both consumers and producers are politically organized and that they lobby simultaneously. This assumption differs from Anderson et al. (2004) who assume that consumers are not organized - or do not effectively lobby. Foreign producers and consumers are typically assumed to be politically unorganized.

${ }^{4}$ The common-agency literature (e.g. Bernheim and Whinston, 1986) states that a 'truthful' contribution schedule reflects the true preferences of an interest group. In these studies, it implies that interest groups set their lobby contributions in accordance with their expected surplus income and how this is marginally affected by the standard. We refer to Swinnen and Vandemoortele (2011) for a proof of the truthfulness of the contribution schedules in this framework.

${ }^{5}$ This objective function implies that a government has no other interest in the standard than how it affects interest groups' surplus incomes and contributions. However, governments may value standards for additional reasons. For example, higher standards may require a larger bureaucracy, leading to higher budgets for and control by the government. The studies in this field typically abstract from these additional objectives.
} 


\section{KU LEUVEN}

$\sum_{j} \alpha_{j} \frac{\partial \Pi_{j}\left(s^{*}\right)}{\partial s}+\frac{\partial W\left(s^{*}\right)}{\partial s}=0$

Optimality condition (3) implicitly defines the politically optimal standard as a function of several variables, such as lobbying effectiveness, consumer preferences, and implementation costs of (domestic and foreign) producers. ${ }^{6}$ This has some straightforward implications. First, a change in an interest group's effectiveness affects $S^{*}$. The effect depends on the relative benefits of the standard for the interest group. More specifically, an interest group's higher effectiveness leads to a higher standard, if and only if this interest group gains from a higher standard, and vice versa. Second, an exogenous change in consumers' preferences for standards affects the politically optimal standard. Higher consumer preferences, for example for safety or quality, lead to higher contributions in favor of public standards and thus a higher standard, and vice versa. Third, a higher implementation cost for domestic producers leads to lower standards as producers contribute less. A higher implementation cost for foreign producers may increase or decrease the politically optimal standard, depending on other factors. On the one hand, the resulting larger price effect results in lower consumer benefits and contributions. On the other hand, it increases the surplus incomes and contributions of domestic producers. The net effect depends on the relation between domestic production and consumption, the functional forms of the various functions, and the relative benefits and political effectiveness of the different interest groups. Finally, an important general implication is that either interest group may lobby in favor of or against standards, and that the political equilibrium may be affected by various factors.

\section{Trade and the Political Economy of Public Standards}

An important aspect of public standards which has attracted substantive attention is their potential use as 'protection in disguise' (Vogel, 1995). In fact, many studies on (the political economy of) standards in open economy models consider standards as protectionist instruments (Anderson et al., 2004; Fischer and Serra, 2000; Sturm, 2006).

To analyze this issue it is important to first clarify 'protectionism'. Standards can be set to benefit ('protect') producer or consumer interests. As with trade restrictions, standards may either harm or benefit producers. Hence, if we define 'protectionism' as producer protectionism, there is no ex ante reason to identify standards with protection. Additionally, while almost all standards affect trade, there is no simple relation between 'trade distortions' and 'producer protection'. In this section, we first analyze the relation between trade and standards. We then identify under which conditions standards reduce trade, i.e. act as 'trade barriers', or enhance trade, i.e. act as 'trade catalysts'. Finally we compare political and social optima of standards and evaluate the 'standards-as-protection' argument.

\footnotetext{
${ }^{6}$ Formal derivations how these variables affect the politically optimal standard are in Swinnen and Vandemoortele (2011).
} 


\subsection{Comparative Advantage and Compliance with Standards}

Standards and trade are interrelated in several ways. First, trade affects a standard's net impact on interest groups and hence their lobby contributions and relative influence. For example, for a given consumption level, with larger imports and lower domestic production, the effect of standards on producers' surplus incomes is smaller and producers' contributions and relative influence lower. Vice versa, for a given level of domestic production, more imports and higher consumption levels imply larger effects on consumer surplus and therefore higher consumer contributions and relative influence.

Second, standards may affect the comparative cost advantage between domestic and foreign producers, as standards may affect the production costs of foreign and domestic producers differently. Standards increase production cost advantages when they reinforce scale economies but not when they have a scale neutral impact or reinforce scale diseconomies. Differences in these effects induce different reactions to standards by domestic producers, but the effects are conditional. Producers oppose standards more (or support them less) if they have a comparative disadvantage and standards reinforce this, compared to when standards are scale neutral. The opposite holds when standards reduce the comparative disadvantage vis-à-vis foreign producers. Similarly, producers support standards more (or oppose less) if standards reinforce a comparative advantage - and vice versa.

Third, standards may have an impact on countries' terms of trade if the standard-imposing country is a large economy importing a significant share of the world market (Baldwin, 2000). When a large country's imports decrease due to a standard, it depresses the world price of the unregulated product. If demand is not perfectly inelastic, the standard's price effect is less pronounced as in the small country case.

Notice that, although these factors do relate standards and trade, they do not say anything about standards being protectionist measures.

\subsection{Catalysts or Barriers to Trade and Welfare}

Standards always affect trade. Only in very special circumstances, when the effect on domestic production exactly offsets the effect on consumption, do standards not affect trade. When standards reduce trade, they are 'trade barriers'. However, standards are 'catalysts to trade' when imports increase (Maertens and Swinnen, 2007). This is the case when the consumption increase (decrease) from the standard is larger (smaller) than the increase (decrease) in domestic production. Moreover, as we discuss next, whether trade flows increase or decrease upon introduction of a standard does not automatically relate to producer protectionism.

To evaluate tariffs in traditional trade theory one compares politically chosen tariffs to the socially optimal trade policy. The political equilibrium is said to be welfare reducing (suboptimal) when the politically optimal tariff differs from the socially optimal tariff. In a small open economy, this analysis leads to the well-known result that the socially optimal tariff level is zero and free trade is optimal.

Swinnen and Vandemoortele (2011) use the same approach to assess whether public standards are set at suboptimal levels by comparing the politically to the socially optimal standard in a small open economy (i.e.

Published version: http://dx.doi.org/10.1017/S1474745612000213 


\section{KULEUVEN}

abstracting from potential terms-of-trade effects). The social optimum is the standard $S^{\#}$ that maximizes the welfare function as defined in equation $(2),{ }^{7}$ determined by:

$$
\sum_{j} \frac{\partial \Pi_{j}\left(s^{\#}\right)}{\partial s}=0
$$

subject to $s^{\#} \geq 0$. Comparing conditions (3) and (4) reveals that the politically optimal standard only equals the socially optimal one when all interest groups are equally effective, and/or when all interest groups' maximum surplus incomes are attained at the social optimum. Notice that the socially optimal standard may be positive. In this case the standard may affect ('distort') trade flows but this change is socially optimal (from an economy's domestic perspective).

Consider the case where the only interest groups are domestic producers and consumers. If their political effectiveness differs, the political and social outcomes diverge (abstracting from the case where the social optimum maximizes both consumers' and producers' surplus income), but this divergence may go in either direction. Hence, in comparison to the social optimum, the politically optimal standard may be too high or too low.

If the producers' interest group is more effective than the consumers' interest group, the politically optimal standard will be too high when producers' surplus income is increasing in the standard at the social optimum. This is more likely when the standard's impact on domestic production costs is small, when the standard reduces (reinforces) diseconomies (economies) of scale, and when the standard's price effect is large (which is more likely in a small-country case). The resulting 'over-standardization' creates higher surplus income for producers. Inversely, when producers' surplus income is decreasing in the standard at the social optimum, the resulting 'under-standardization' reduces the standard's negative impact on producers. Hence domestic producers benefit from this under-standardization such that the too-low standard also serves as protection in disguise. In both cases the suboptimal standard distorts trade to the advantage of the domestic producers.

Similarly, a higher effectiveness of the consumers' interest group results in a too-high (too-low) standard when consumers' surplus income is increasing (decreasing) at the social optimum. Whether these suboptimal standards are 'protectionist' or not depends on the standard's impact on domestic producers. However, when only domestic producers and consumers are politically organized, the standard's marginal impacts on the interest groups' surplus incomes have opposite signs at the social optimum (except for the trivial case where both equal zero and the social optimum coincides with the political optimum). Hence when the politically optimal standard is set too high, producers lose from the over-standardization. The politically optimal standard is then, although suboptimal, not 'protectionist'. Vice versa, producers are also hurt by under-standardization. In both cases the suboptimal standards result in trade distortions that do not protect domestic producers.

\footnotetext{
${ }^{7}$ This is consistent with the standard definition in the international trade literature: the socially optimal policy maximizes domestic welfare (Dixit and Norman, 1980; Grossman and Rogoff, 1995; Feenstra, 2004; Gaisford and Kerr, 2007).
} 


\section{$4 \quad$ Concluding Comments}

In this paper we reviewed insights from the emerging literature on the political economy of public standards. There is an important relationship between trade and standards. Trade affects the net impact of standards on interest groups and hence their lobby contributions. Standards may also affect comparative cost advantages between countries, which may lead to either higher or lower standards, and standards may have terms-of-trade effects when the standard-imposing country is a large economy. Standards may be 'barriers' to trade but also 'catalysts' to trade, and both 'under-' or 'over-standardization' may occur, depending on a variety of factors. In this way, standards may serve as protection in disguise, or not.

These findings imply that the effects of specific standards should be analyzed carefully before categorizing them as protectionist instruments. Empirical analyses are therefore essential. An overview of empirical studies analyzing the impact of standards on trade and welfare is provided by Maskus and Wilson (2001) who conclude that stronger standards in developed countries may either diminish trade opportunities or expand market access for developing countries. Recent empirical studies also provide conflicting evidence. For example, Anders and Caswell (2009) find that US seafood safety standards had a negative impact on developing countries' exports to the US while Maertens and Swinnen (2009) document that horticultural exports from Africa to the EU increased strongly despite tightening standards over the past decade. 


\section{REFERENCES}

Anders, S. M. and J. A. Caswell (2009), 'Standards as Barriers versus Standards as Catalysts: Assessing the Impact of HACCP Implementation on U.S. Seafood Imports', American Journal of Agricultural Economics, 91(2): 310-321.

Anderson, K., R. Damania, and L. A. Jackson (2004), 'Trade, Standards, and the Political Economy of Genetically Modified Food', World Bank Policy Research Working Paper, 3395.

Bagwell, K. and R. Staiger (2001), 'Domestic Policies, National Sovereignty and International Economic Institutions', Quarterly Journal of Economics, 116(2): 519-562.

Baldwin, R. E. (2000), 'Regulatory Protectionism, Developing Nations and a Two-Tier World Trading System', in S. Collins and D. Rodrik (eds.), Brookings Trade Forum, Washington, DC: Brookings Institution.

Barrett, S. (1994), 'Strategic Environmental Policy and International Trade', Journal of Public Economics, 54(3): 325-338.

Barrett, C. B. and Y. Yang (2001), 'Rational Incompatibility with International Product Standards', Journal of International Economics, 54(1): 171-191.

Bernheim, B.D. and M.D. Whinston (1986), 'Menu Auctions, Resource Allocation, and Economic Influence', Quarterly Journal of Economics, 101(1): 1-31.

Bockstael, N. (1984), 'The Welfare Implications of Minimum Quality Standards', American Journal of Agricultural Economics, 66(4): 466-471.

Boom, A. (1995), 'Asymmetric International Minimum Quality Standards and Vertical Differentiation', The Journal of Industrial Economics, 43(1): 101-119.

Chen, M. X. and A. Mattoo (2008), 'Regionalism in Standards: Good or Bad for Trade?', Canadian Journal of Economics, 41(3): 838-863.

Cook, D. C. and R. W. Fraser (2008), 'Trade and Invasive Species Risk Mitigation: Reconciling WTO Compliance with Maximising the Gains from Trade', Food Policy, 33(2): 176-184.

Cooper, R. and W. Ross (1985), 'Product Warranties and Double Moral Hazard', Rand Journal of Economics, 16(1): 103-113.

Copeland, B. R. and M. C. Taylor (1995), 'Trade and Transboundary Pollution', American Economic Review, 85(4): 716-737.

Costinot, A. (2008), 'A Comparative Institutional Analysis of Agreements on Product Standards', Journal of International Economics, 75(1): 197-213.

Crampes, C. and A. Hollander (1995), 'Duopoly and Quality Standards', European Economic Review, 39(1): 71-82.

Dixit, A. and V. Norman (1980), Theory of International Trade, Cambridge: Cambridge University Press.

Emons, W. (1988), 'Warranties, Moral Hazard, and the Lemons Problem', Journal of Economic Theory, 46(1): 16-33.

Feenstra, R. (2004), Advanced International Trade: Theory and Evidence, Princeton: Princeton University Press.

Fischer, R. and P. Serra (2000), 'Standards and Protection', Journal of International Economics, 52(2): 377 400.

Fulton, M. and K. Giannakas (2004), 'Inserting GM Products into the Food Chain: The Market and Welfare Effects of Different Labeling and Regulatory Regimes', American Journal of Agricultural Economics, 86(1): 42-60.

Gaisford, J. D. and W. A. Kerr (eds.) (2007), Handbook of International Trade Policy, Cheltenham, UK: Edward Elgar Publishing

Grossman, G. M. and E. Helpman (1994), 'Protection for Sale', American Economic Review, 84(4): 833850.

Grossman, G. M. and K. S. Rogoff (1995), Handbook of International Economics, Vol. III, Amsterdam: Elsevier North Holland.

Hensen, S. and J. S. Wilson (eds.) (2005), The WTO and Technical Barriers to Trade, Cheltenham, UK: Edward Elgar Publishing.

Jeanneret, M. and T. Verdier (1996), 'Standardization and Protection in a Vertical Differentiation Model', European Journal of Political Economy, 12(2): 253-271.

Leland, H. E. (1979), 'Quacks, Lemons, and Licensing: A Theory of Minimum Quality Standards', Journal of Political Economy, 87(6): 1328-1346.

Maertens, M. and J. F. M. Swinnen (2007), 'Standards as Barriers and Catalysts for Trade, Growth and Poverty Reduction', Journal of International Agricultural Trade and Development, 4(1): 47-62.

Maertens, M. and J. F. M. Swinnen (2009), 'Trade, Standards and Poverty: Evidence from Senegal', World Development, 37(1): 161-178.

Marette, S. and J. C. Beghin (2010), 'Are Standards always Protectionist?', Review of International Economics, 18(1): 179-192.

Maskus, K. and J. S. Wilson (eds.) (2001), Quantifying the Impact of Technical Barriers to Trade: Can It Be Done?, Ann Arbor MI: Michigan University Press.

Mussa, M. and S. Rosen (1978), 'Monopoly and Product Quality', Journal of Economic Theory, 18(2): 301317. 


\section{KU LEUVEN}

North, D. C. (1990), Institutions, Institutional Change and Economic Performance, New York: Cambridge University Press.

Roe, B. and I. Sheldon (2007), 'Credence Good Labeling: The Efficiency and Distributional Implications of Several Policy Approaches', American Journal of Agricultural Economics, 89(4): 1020-1033.

Ronnen, U. (1991), 'Minimum Quality Standards, Fixed Costs, and Competition', RAND Journal of Economics, 22(4): 490-504.

Schleich, T. (1999), 'Environmental Quality with Endogenous Domestic and Trade Policies', European Journal of Political Economy, 15(1): 53-71.

Sheldon, I. (2012), 'North-South Trade and Food Standards: What Can General Equilibrium Analysis Tell Us?', The World Trade Review, this issue.

Spence, M. (1976), 'Product Differentiation and Welfare', American Economic Review, 66(2): 407-414.

Sturm, D. M. (2006), 'Product Standards, Trade Disputes, and Protectionism', Canadian Journal of Economics, 39(2): 564-581.

Swinnen, J. F. M. and T. Vandemoortele (2008), 'The Political Economy of Nutrition and Health Standards in Food Markets', Review of Agricultural Economics, 30(3): 460-468.

Swinnen, J. F. M. and T. Vandemoortele (2009), 'Are Food Safety Standards Different from Other Food Standards? A Political Economy Perspective', European Review of Agricultural Economics, 36(4): 507-523.

Swinnen, J. F. M. and T. Vandemoortele (2011), 'Trade and the Political Economy of Food Standards', Journal of Agricultural Economics, 62(2): 259-280.

Sykes, A. O. (1995), Product Standards for Internationally Integrated Goods Markets, Washington: The Brookings Institution.

Thilmany, D. D. and C. B. Barrett (1997), 'Regulatory Barriers in an Integrating World Food Market', Review of Agricultural Economics, 19(1): 91-107.

Tian, H. (2003), 'Eco-labelling Scheme, Environmental Protection, and Protectionism', Canadian Journal of Economics, 36(3): 608-633.

Tirole, J. (1988), The Theory of Industrial Organization, Cambridge, MA: MIT Press.

Valletti, T. M. (2000), 'Minimum Quality Standards under Cournot Competition', Journal of Regulatory Economics, 18(3): 235-245.

Vogel, D. (1995), Trading Up: Consumer and Environmental Regulation in a Global Economy, Cambridge, MA: Harvard University Press. 
Research Coordination Office

Huis Bethlehem

Schapenstraat 34

B-3000 Leuven

Tel.: +3216324065

Fax: +3216324198

onderzoek@kuleuven.be

www.kuleuven.be 